方法の開発も進んでいる.オール生分解性プラスチック材 料成形としてPLA を，また，高温での応用も可能なリサ イクル PET を使った成果報告があった（B-214，215）.

材料面からの取組みとして，放熱性の良い複合材料用い ることで，熱を効率よく伝達（放熱）する・蓄積する応用 への可能性を探る研究 (H-101), リサイクル PET/PP の 温度・湿度安定性を相溶化剂の効果を含めて把握しょうと する研究 $(\mathrm{H}-103)$, そして, POM と PLA のブレンド材 料の勒性と耐衝撃性を改善させるための研究 $(\mathrm{H}-104)$ も あり，革新的材料を用いた環境配慮型製品を目指す研究の 重要性を感じた。

プロセス面からの取組みとしては，現行設備を大幅変更 することなくサイクルタイム短縮が可能なパルス冷却の研
究（B-212）や冷却速度を制御し, 収縮低減, 精度向上を 狙った研究 (B-216) も省エネという観点から顧客価值を 提供できる興味深いものであった．また，射出プレス成形 に関する進展もあり，電動化・型締高速化・低射出圧化も， 省エネ化という視点だけでなく製品の品質向上にも連動し ている（H-107，108）。また, 今後, 装置の小型化も進む 可能性がある.

その他，CAEでは，空間的に不均一な固化層生成が製 品歪に与える影響や，オーバーモールディングの現象解明 を行うための報告があった（B-209，211）。また，評価関 連としては, ウエルドラインの目視検査を精度良く, 客観 的に評価するために単純化した試験片にてトライした報告 (B-210) 等があった.

\title{
一般セッション
}

\section{紡糸・フィルム成形 $(\mathrm{E}-101 \sim \mathrm{E}-108)$}

紡糸・フィルム成形セッションは，年次大会初日の午前 中に開催され，8件の講演が行われ，非常に活発で本質的 な質疑応答が行われた。フィルム成形に関しては延伸及び 多層成形の実験的, 計算的アプローチがされ, 繊維に関し ては立体規則性を制御した繊維及びその不織布の開発に関 する発表があった。 また繊維では表面粗度の解析や紡糸シ ミュレーション技術に関する発表もあった。 発表内容はそ れぞれ専門性が高く一文でまとめられるものではないが, 延伸, 多層, 繊維に分類し要点のみ以下にまとめる.

延伸に関しては 2 件の報告がされた. 光学フィルムにお いて延伸過程の複屈折挙動は大変興味深いが，これを二軸 延伸機によりオンラインで測定したところ, MD 延伸で増 加した複屈折は TD 延伸により負まで減少し緩和によりゼ ロに漸近する傾向を示した. TD 延伸後の保持時間を変え ると最終の複屈折の值が異なる, という点は興味深い. ま た横延伸工程のフィルム変形挙動シミュレーションでは, 気流解析と組み合わせることにより衝突噴流の伝熱をよく

\footnotetext{
* Shiode, Hiorohisa

三井化学(侏)マテリアルサイエンス研究所

袖ヶ浦市長浦 580-32（テ299-0265）
}

表現できた。このように周囲の場の解析と組み合わせるこ とは重要な解析方法であると考えられる.

多層成形に関しては 2 件の報告がされた．小型押出機 2 台とフィードブロックによる多層成形で，包み込みあるい は界面荒れが起こるときの界面の様子を観察した．界面不 良現象の理解に非常に役立つものと考えられる。また多層 成形の 3 次元粘弾性流動シミュレーションにより伸長特性 と包み込み現象の関係を整理する試みがあった．理論面か らのアプローチなので沉用的な情報が得られる。

繊維に関しては 4 件の報告がされた。低立体規則性 PP に高立体規則性 PP を添加することにより弾性率, 融点, 可紡性が上昇した. 改めて低立体規則性 PP の成形性, 瀻 維物性の改良が可能であることが示された．またこの低立 体規則性 PP に高立体規則性 PP を添加した繊維でつくら れた不織布の性能に関して報告があった. 高立体規則性 PP の添加量に依存して不織布の弾性回復率を制御できること がわかった。

本セッションは, 実験と計算の両面から解析が行われ, 現象の理解が進んでいる．引き続きさまざまな角度からの 解析が行われることを期待する.

\section{一般セッション}

\section{アロイ・ブレンド・複合材料（F-209～F-214）}

年次大会 2 日目, 最終日の最終時間に加えて, 同様に材 料系の特別セッションである「新材料・高機能材料技術」 の裏ということもあり聴講者数が心配されたが, そのよう な心配は無用だったようである，聴講者も多く，質疑応答

\footnotetext{
* Nakai, Asami

京都工芸繊維大学伝統みらい研究センター

京都市左京区松ヶ崎御所海道町（６006-8585）
}

も活発に行われた。

さて本セッションでは，一般講演 6 件の発表が行われた (ここで，上述の「新材料・高機能材料技術」においても 複合材料関連の講演が多く行われたことを付記しておく). いずれもポリマーブレンド $(\mathrm{F}-209,211)$ ，フィラーおよ びナノチューブ充填 $(\mathrm{F}-210,212)$, 繊維強化 $(\mathrm{F}-213,214)$ による力学的特性や機能性の向上に関する講演であった. 
一般に，例えば連続繊維強化複合材料においては，その材 料の組み合わせにより力学的特性が決定されるが, これら のブレンドや充填系の材料においては, 成形加工時にポリ マーや充填材の配向や分散が変化するため, 材料の機能を 発現するための成形加工を行う必要があり，その重要性を 改めて認識した次第である. これらを逆手に取って, フィ ラーの高配向化による熱伝導率の向上 $(\mathrm{F}-210)$, カーボ ンナノチューブの局在化による半導電性の向上 $(\mathrm{F}-212)$, 成形加工時の流動による In-situ 繊維化（F-213）など,
成形加工を利用した材料の高機能化が行われており，大変 興味深かった。

従来，成形加工学会においては「複合材料」のセッショ ンは人が集まらないというジンクスがあったが，ここ数年， 本学会の中で「材料」が大きな地位を占めつつあり, 新材 料の開発のみならず，材料の機能を引き出すための成形加 工が注目されている. 今後もこの分野の更なる進展が期待 される。

\section{一般セッション}

\section{エ業レオロジー（F-204～F-207）}

服部 高 明*

今回の「工業レオロジー」での報告内容を大別すると， 成形加工される材料あるいは原料のレオロジー特性を中心 とした報告が 3 件, シミュレーションによる成形加工時の 現象解明が 1 件であった。

近年の諸先輩方の言葉をお借りすれば，「工業レオロ ジー」とは, 成形加工における基礎的な研究分野をカバー するセッションとのことであるが, 周知の通り, 高分子の 成形加工とレオロジーとは切っても切り離せない関係にあ り, レオロジーを基礎に置いた研究報告は他のセッション にも散見される. それも大きな要因となっているのであろ うが，今回の本セッションも報告件数で判断する限りにお いてはやや低迷しているとの感は否めない. しかし, 実際 のセッションは聴講者数および質疑ともに比較的盛況で あったのではないだろうか.

材料あるいは原料のレオロジー特性に関わる報告では, それぞれの本質に関わる特性の由来が少なからず質疑応答

\footnotetext{
* Hattori, Takaaki

日本ポリエチレン侏）研究開発センター

川崎市川崎区夜光 2-3-2（テ 210-8548）
}

で話題となっていた。いずれも研究対象となっている現象 は非常に興味深いが，取り扱われている材料が単純でない ためか, 現段階では現象論的な議論に留まっている傾向が 見受けられた。 今後, それぞれのレオロジー特性発現のメ カニズムが解明されていくによって, 当該技術あるいは関 連技術が一層発展していくことに期待したい.

一方, シミュレーションによる現象解明は, ポリオレフィ ンのペレット化に関するものであったが，ペレットの形状 は保管や輸送時の様々な特性のみならず成形時の押出特性 にも影響することから，当業者は以前から注目している事 柄の一つであると思われる. 案の定，企業での現業に関連 するであろう派生的な質疑が会場のあちらこちらから繰り 出され，盛り上がりを見せた。 ポリオレフィンは熱可塑性 樹脂の全生産量の約半分を占めている汎用ながらも重要な 樹脂であり, その研究報告は現象が関係する樹脂量として も極めて大きな内容であったと考える.

最後に自戒の念を含めて申し添えるならば，本セッショ ンでの企業研究者の報告がもっと活発になるよう皆様方に ご協力をお願い申し上げたい.

\section{一般セッション}

CAE $(D-101 \sim D-104)$

瀬 戸 雅 宏*

本セッションでは, プラスチック成形加工における CAE 技術に関する 4 件の講演があった. 昨今の経済情勢の悪化 により，ものづくり分野において研究，製品開発の効率化, 低コスト化はますます重要性を増しており，CAE 技術の 確立，導入が必要不可欠である.

射出成形プロセスにおけるコストダウンの一手法として， 成形サイクルの短縮化がある，杉尾らは金型温度解析を非 定常で計算する手法を開発し, 種々の金型材質や冷却回路 レイアウトにおいて, 実験結果と解析結果の比較検証を

\footnotetext{
* Seto, Masahiro

金沢工業大学 ものづくり研究所

白山市八束穂 3-1（９24-0838）
}

行った. 非定常金型温度解析を実施することで，成形サイ クル内や定常状態の金型温度が精度よくシミュレートされ ていた．金型温度の高精度化は，成形サイクルの短縮化だ けではなく，そり変形等の不良現象の予測にも有効である。 金型試作回数の低減もコストダウンに大きく寄与する. 特に射出成形品のそり変形は予測が難しく, CAE を活用 した金型設計の最適化が必要である. 従来の遺伝的アルゴ リズムによる最適化手法では，計算に多くの時間を要する 問題があった. 山田らは各設計変数に対応する染色体につ いて，個別に交配と突然変異の遺伝子操作を行うことで設 計変数の探索範囲を狭くし，短時間で最適解を算出できる 手法を報告した．本手法が実用化されれば，金型設計の大 